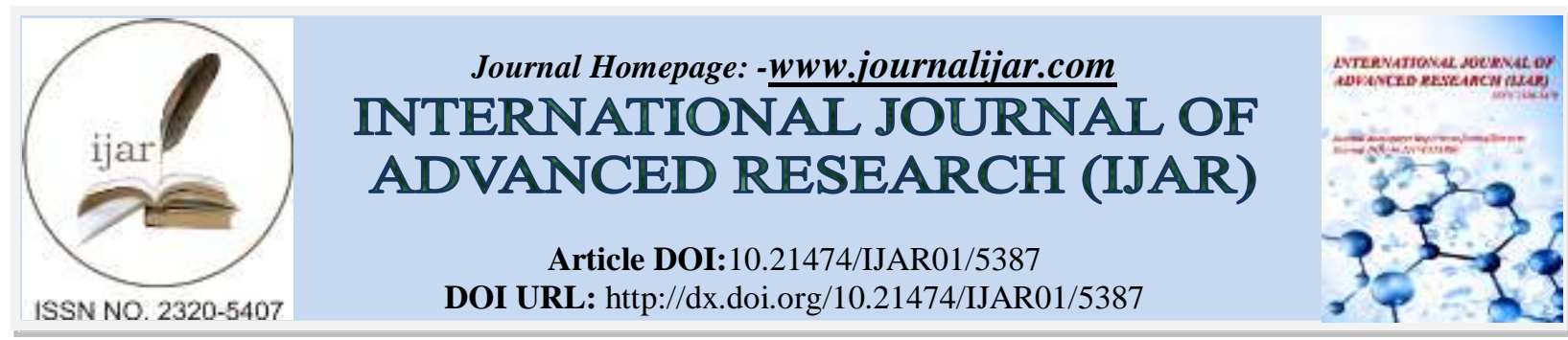

RESEARCH ARTICLE

\title{
AN EMPIRICAL ANALYSIS OF THE DETERMINANTS OF PROFITABILITY OF PRIVATE SECTOR BANKS.
}

\section{Subham Dastidar' ${ }^{1}$ and Subhas Chandra Sarkar ${ }^{2}$.}

1. SubhamDastidar, RBC Evening College, Naihati, West Bengal - 743165 .

2. Prof. Dr. Subhas Chandra Sarkar, Department of Commerce, University of Kalyani, West Bengal.

\section{Manuscript Info}

...........................

Manuscript History

Received: 10 July 2017

Final Accepted: 12 August 2017

Published: September 2017

Key words:-

Private Bank, Profitability, Macro

Economy, Panel Data, And India.

\section{Abstract}

The entry of new generation private sector banks influenced the dynamics of the business of Indian banks, particularly among old private sector banks. This paper has made an attempt to investigate the impact of bank specific and macroeconomic determinants on the overall profitability of old and new private sectors banks in India. Internal factors include individual bank specific characteristics which directly affect the bank's profitabilityand influenced by the decisions of internal management and that differs from bank to bank. On the other hand, external factors considered in the study include macroeconomic determinants which are beyond the control of the banks and they are bound to accept them. The results indicated that the magnitudes of the impact of the internal factors are similar in nature for both categories of banks. Among the indicators, the efficiency of bank management is the most important determinant of bank's profitability, while liquidly has the least impact on it. Financial instability made old private sector banks more vulnerable compared to new private sector banks. However, post financial crisis situation is positive for new private sector banks as estimated from the coefficients of panel data regression. Favourable macroeconomic situation after the financial crisis and rapid adoption of technology in banking operation has helped new private sector banks outperform other categories of banks on profitability.

Copy Right, IJAR, 2017,. All rights reserved.

\section{Introduction:-}

Commercial banks occupied a crucial position in the development efforts and act as a catalyst for economic growth of the country. The Indian financial sector did not provide fair and equal chance to all its players, where public sector banks were enjoyed some privileges and dominated the banking sector for several decades (Rajan, 2003). Financial reforms have brought sea changes in the banking sector as a whole. However, the key concern is to sustain profitability of the commercial banking industry. The opening up of the banking sector to private players has increased competition between bank groups, particularly between public and private sector banks. Private sector banks with their technology driven services and best management practices have managed to sustain their profitability position. However, increased competition has put pressure on the profitability of public sector banks. As far as growth prospects are concerned, significant differences were found in terms of profitability and soundness of business, indicating that private sector banks are in a better position in the industry (Shukla, 2016). With this 
background, the present chapter compares the determinants of profitability of new and old private sector banks. The study investigates the determinants of profitability of banks by using a number of indicators, which depends largely on internal and macroeconomic factors. Among the factors that affect the profitability of banks are broadly categorized into internal and external factors. Internal factors are basically determined by internal decision taken by the management of banks, while macroeconomic factors are generally beyond the control of the banks (Ongore and Kusa, 2013) $)^{3}$.

Usually profitability of any bank is generally measured by return on average assets, return on equity and net interest margin. It is genenrally expressed as a function of internal factors. In most studies, variables such as bank size, operational efficiency and the capital ratio serve as internal determinants of banks' profitability. Besides, the ownership structure is another bank-specific variable, which is widely accepted to affect banks' performance (Dietrich and Wanzenried, 2014). The external determinants of banks' profitability include factors, such as the inflation rate, GDP growth, taxation, and variables representing industry characteristics. It is expected to have positive relationship between inflation, GDP growth, and banks' profitability (Athanasoglou, 2008).

The private sector banks give tough competition to public sector banks in terms of earnings, management efficiency and asset quality (Athanasoglou et al, 2005). Using CAMEL indicators to compare the performance of public and private sector banks showed significant difference in performance in Capital Adequacy, Asset Quality and Earning Capacity of public and private sector banks in India, while there is no significant difference in the Management, Liquidity Position and Sensitivity to market risk of the two different bank groups. Non-performing assets (NPA) affected significantly the performance of the banks (Devanadhen, 2013).

In the present liberalized regime, public sector banks face competition with three groups of private sector banks, old private sector banks, new private sector banks and foreign banks. All banks are subject to same prudential norms and regulatory requirements like cash reserve ratio, liquidity ratio etc. Government support to the public sector banks has been coming down significantly after liberalization. The overall financial performance, measured through different indicators of profitability shows that new private sector banks have improved their performance as compared with old private sector banks. In fact the performance of the latter has deteriorated once we compare from the perspective of the financial crisis that happened during beginning of the new decade. In the present paper, our objective is to investigate the factors influencing banks' profitability. The determinants of profitability are generally divided into two groups - bank specific factors and external factors. Following CAMEL we have adopted four bank specific determinants of banks' profitability, viz. liquidity, asset quality, soundness and management efficiency. In this paper, GDP growth, inflation, and financial stability are the three macroeconomic indicators used for analysis.

The rest of the paper is organized in the following sections. In section 2, we provide a brief description of the determinants of profitability of banks. Methodology and data used in this study are elaborated in Section 3 . The result of the study is presented in section 4 . The final section concludes the study.

\section{Determinants of Profitability of Banks:-}

We consider three ratios viz. the ratio of net interest income to total income, return on assets, and return on equity which are used as a proxy for banks' profitability. The determinants of profitability of banks are categorized broadly by its internal factors and external factors. Internal factors are also termed as banking industry oriented factors, which is basically individual characteristics of banks that affect performance. Internal factors are analysed through different ratios that can assess the financial performance. The external factors are basically macroeconomic factors, various government decisions and other country specific factors and which affect the entire industry are beyond the control of individual banks.

Bank specific characteristics and macroeconomic factors are the independent variables of the study. The broad groups of indicators adopted under bank specific characteristics that affect banks' profitability are liquidity, asset quality, financial soundness and management efficiency. The ratios are largely drawn from those used by the Reserve Bank of India's supervisory department as part of its CAMELS assessment of banks.

\section{Liquidity:-}

The financial stability of the company can be tested using the liquidity position of banks. Higher liquidity of banks leads to better financial performance. If a bank suffers a sudden shortage of funds, it can use its cash reserves or sell off highly liquid assets to meet its immediate financial obligations. The ratios used under this category are cash 
deposit ratio, investment deposit ratio and deposit to liability ratio. These ratios are also used to assess a banks' ability to pay its short and long-term obligations. These ratios are described as follows.

\section{Cash-Deposit Ratio:-}

Cash in cash-deposit ratio is the cash in hand and balances with RBI. This ratio tells the amount total liquidity the banks have in hand out of total deposit receipt. In other words, this ratio also indicates the amount of cash balance of all branches maintained by the bank to meet its liability. The cash-deposit ratio can be viewed in the context of liquidity. However, with the implementation of technology driven services, such as, use of plastic cards, net banking, National Electronic Funds Transfer (NEFT), and so on, the need for cash to deposit ratio has been reduced.

\section{Investment-Deposit Ratio:-}

Investments in investment-deposit ratio represent total investments, including investments in non-approved securities. This ratio basically gives information that where banks using their deposit may be economic development where bank can put their money for investment so that they can earn more interest.

\section{Deposit-Liability Ratio:-}

Ratio of deposit to total liabilities is commonly used to assess a bank's liquidity compared to its total loans. If the ratio is high, it means banks have enough liquidity to cover any unforeseen fund requirements and vise versa.

\section{Asset Quality:-}

Asset quality of banks has positive influence on the banks' performance. It is obvious that better asset quality fo sters a bank's profitability. Determinants of asset quality have attracted attention in recent research studies. Measures of asset quality are given in brief that follow.

\section{Ratio of secured advances to total advances:-}

Ratio of secured advances to total advances is measured as the sum of advances secured by tangible assets and advances covered by a bank or Government guarantees/advances. This ratio indicates the quality of advances by the bank. Higher ratio indicates better quality.

\section{Ratio of net NPA to net advances:-}

Net NPAs are calculated by deducting provisions from gross NPAs. The net NPA to advances (loans) ratio is used as a measure of the overall quality of the bank's loan book. There is an inverse relationship between this variable with a bank's profitability. In this study, we use the inverse of net non-performing assets. Net non-performing assets is calculated by taking the difference between gross NPAs and provisions. While NPA ratio is calculated by net nonperforming assets divided by advance.

\section{Soundness:-}

Soundness of the banking sector is assessed through the capital adequacy ratio, which is measured a bank's ability to meet time liabilities and dangers like operational risks, credit risks and other risks. RBI recommended a minimum ratio to be kept out by the banking system. This is done on the ground that depositors are secured about their deposits and banks have a cushion for their potential losses. Measures of soundness are discussed in brief that follow.

\section{Capital adequacy ratio Tier-I:-}

Tier-I capital is also referred to as core capital. This includes equity capital and disclosed reserves. This component of a bank's capital essentially serves the purpose of absorbing losses without a bank requiring to ease trading.

\section{Capital adequacy ratio:Tier-II:-}

Tier-II capital, secondary capital of a bank, comprised of undisclosed reserves, general loss reserves, subordinate term debts which can absorb losses in the event of a winding up, and subsequently providing a lesser degree of protection to depositors.

\section{Efficiency:-}

The ratio is used to measure the efficiency and effectiveness of management, which takes decisions according to risk perception. The management controllable factor that determines banks' profitability are business per employee, profit per employee, percentage of non-interest income to total assets and credit-deposit ratio. Rise in management 
efficiency has a positive effect on profitability of banks. The measures of this category are given in a nut shell that follow.

\section{Business per employee :-}

Business per employee is calculated as total business of banks divided by total employees, where business is the sum of deposits and advances.

\section{Profit per employee:-}

Profit per employee is the ratio of net profit to total number of employee.

\section{Other income to total asset:-}

Other income is often referred to as non-interest income, which includes income generated from a variety of services such as trading of securities, wealth management, commission from issuing new equity financing etc. Compared to developed countries Indian banking sector is lagging behind in respect of income from non-interest sources. However, with the growth in economic activity the demand for fee based services has gone up. Non-interest income is growing at faster rates in private sector banks in India as compared with public sector banks.

\section{Credit-Deposit Ratio:-}

This ratio tells how much loan is disbursed out of total deposit. Higher the ratio is better is the bank, if the bank gives loan with high interest rate so that bank can get a good yield.

\section{External Factors/Macroeconomic Factors:-}

The implication of macroeconomic policy in gross domestic product, inflation, interest rate and political instability are also other macroeconomic variables that can affect the performance of banks. For instance, the economic growth affects the demand for banks' products. During any downturn in economic growth the demand for credit falls which, in turn, affect negatively on the profitability of banks. On the contrary, in a growing economy as indicated from positive economic growth, the demand for credit is high due to the nature of business cycle. During boom the demand for credit is high compared to recession (Makkara and Singh, 2013). The same authors stated with respect to the Greek situation that the relationship between inflation level and profitability of bank remains a debatable. The direction of the relationship is ambiguous (Vong and Chan, 2009). In the present study we have considered GDP growth rate and annual inflation as a proxy of macroeconomic indicator which have impact on the performance of banks. These variables are discussed in the paragraphs that follow.

Annual percentage growth rate of GDP at market prices is based on constant local currency of a particular country. GDP is the sum of gross value added by all resident producers in the economy plus any product taxes and minus any subsidies not included in the value of the products. It is calculated without making deductions for depreciation of fabricated assets or for depletion and degradation of natural resources.

Inflation as measured by the consumer price index reflects the annual percentage change in the cost to the normal buyer of obtaining a basket of goods and services that may be settle or changed at specified intervals, such as yearly. The Laspeyres formula is generally used in the estimation of elasticity.

Financial crisis happened in 2008 affected the performance of banking system across the world, which can be included in the empirical model as a dummy of financial stability to analyse the effect of crisis on Indian banking system.

\section{Data and Methodology:-}

The database created by Reserve Bank of India from Annual Accounts of Banks is used for the study. The database contain information on banks which are included in second Schedule of the RBI Act, 1937, known as schedule commercial banks. It constitutes bank group wise selected ratios of scheduled commercial banks. For the purpose of the study we consider private sector banks which included both old private sector and new private sector banks. The data was collected for the time period of 15 years $(2000-2014)$ for private sector banking space. Depending on availability and continuity of data we have considered 7 banks from new private sector and 12 banks from old private sector banks. 
The dataset for type of research is the combination of both cross-sectional studies and time-series studies. We can pull the data to arrive at a bigger dataset and run simple pooled OLS regression. But since we are dealing with the same entities over the time periods we can attempt to utilize panel regression methods also, which examine individual specific effects, time effect or both, in order to deal with observed or unobserved heterogeneity, which are not captured in the pooled regressions. These effects are either fixed or random. The selection of appropriate model for regression depends on the appropriate methodology, which has been elaborated as in the following paragraphs.

A fixed effect model investigates when intercepts vary across group or time period, while a random effect model investigates the differences in error variance components across individual or time period. Following Green (2008) we have adopted panel data regression model. If individual $\mathrm{u}_{\mathrm{i}}$ (cross sectional and time specific effect) does not exist (i.e. $\mathrm{u}_{\mathrm{i}}=0$ ), OLS produces a consistent parameter estimates.

The impact of different internal characteristics and other external factors on bank's profitability can be represented in the following equation.

$$
\pi_{i t}=\alpha_{0}+\alpha_{2} X_{i t}^{1}+\alpha_{2} X_{i t}^{2}+\alpha_{3} X_{i t}^{3}+\alpha_{4} X_{i t}^{4}+\alpha_{5} Y_{i t}+\alpha_{6} I N F_{i t}+D_{i t}+\varepsilon_{i t},\left(u_{i}=0\right)
$$

Where, $\pi_{i t}=$ Profitability of $\mathrm{i}^{\text {th }}$ bank at time $\mathrm{t}$ as measured by different profitability indicators.

$X_{i t}^{1}=$ Capital adequacy of $\mathrm{i}^{\text {th }}$ bank at time $\mathrm{t}$

$X_{i t}^{2}=$ Liquidity of $\mathrm{i}^{\text {th }}$ bank at time $\mathrm{t}$

$X_{i t}^{3}=$ Asset quality of $\mathrm{i}^{\text {th }}$ bank at time $\mathrm{t}$

$X_{i t}^{4}=$ Management efficiency of $\mathrm{i}^{\text {th }}$ bank at time $\mathrm{t}$

$Y_{i t}=$ Gross Domestic Product (GDP) at time $\mathrm{t}$

$I N F_{i t}=$ Annual inflation rate at time $\mathrm{t}$

$D_{i t}=$ Financial crisis dummy

$\varepsilon_{i t}=$ Error term

If individual effect $u_{i}$ is not zero in longitudinal data, the core assumptions of OLS estimation may be influenced by heterogeneity. The panel data regression gives an approach to manage these issues.

Panel data is widely used in empirical analysis because the longitudinal data have higher variability and allow exploring more issues as compared to cross-sectional or time-series data (Kennedy, 2008). As per Baltagi (2001), panel data are more informative, greater fluctuating, less collinearity among the factors, more degrees of freedom and greater efficiency. Panel data regression analyzes fixed and random effect of individual and time. The fundamental difference between fixed and random effect models lies in the role of dummy variables. The functional forms of one-way fixed and random effect models are according to the following.

Fixed effect model (FE) $\quad: \pi_{i t}=\left(\alpha+u_{i}\right)+\beta X_{i t}+v_{i t}$

Random effect model (RE) $\quad: \pi_{i t}=\alpha+\beta X_{i t}+\left(u_{i t}+v_{i t}\right)$

Where $u_{i}$ is a fixed or random effect specific to individual group or time period that is not included in the regression, and errors are independent and identically distributed.

The following are the list of private banks considered in this study.

\begin{tabular}{|l|l|}
\hline New Private Banks & Old Private Banks \\
\hline Axis Bank & Catholic Syrian Bank \\
\hline Development Credit Bank & City Union Bank \\
\hline HDFC Bank & Dhanlaxmi Bank \\
\hline ICICI Bank & Federal Bank \\
\hline Indusind Bank & ING Vysya Bank \\
\hline Kotak Mahindra Bank & Jammu \& Kashmir Bank \\
\hline Yes Bank & Karnataka Bank \\
\hline & KarurVysya Bank \\
\hline & Lakshmi Vilas Bank \\
\hline & Ratnakar Bank \\
\hline & South Indian Bank \\
\hline & Tamilnad Mercantile Bank \\
\hline
\end{tabular}




\section{Results:-}

Table 1 presents the summary statistics, including average, standard deviation, minimum and maximum value of the indicators used to investigate financial performance during the study period. Among the indicators under liquidity it is observed that, during the total study period, average cash reserve ratio is 7.03 for new private sector banks whereas it is 6.93 for old private sector banks. Investment deposit ratio is 44.76 for new private sector banks against 36.98 for its counterpart. However, total deposit to total liability ratio is 85.82 , which is higher, for old private sector banks as against 71.38 for new private sector banks (Figure 1). Therefore, except the ratio of deposit to total liability, other two liquidity ratio is lower for old private sector banks.

Table 1:-Summary statistics of the determinants of performance, 2000-2014.

(New Private Sector Banks)

\begin{tabular}{|l|c|c|c|c|}
\hline Variables & Mean & StDev & Min & Max \\
\hline Liquidity - & & & & \\
\hline Cash deposit ratio & 7.03 & 2.89 & 3.03 & 13.62 \\
\hline Investment deposit ratio & 44.76 & 8.77 & 31.03 & 64.19 \\
\hline Ratio of deposit to total liability & 71.38 & 9.24 & 51.84 & 85.15 \\
\hline Asset quality- & & & & \\
\hline Ratio of secured advances to total advances & 80.21 & 10.78 & 45.22 & 97.16 \\
\hline Ratio of net NPA to net advances & 1.66 & 1.92 & 0.00 & 7.76 \\
\hline Efficiency- & & & & \\
\hline Business per employee & 826.14 & 370.68 & 347.00 & 2220.25 \\
\hline Profit per employee & 7.66 & 5.99 & -10.84 & 21.00 \\
\hline Ratio of non-interest income to total assets & 1.84 & 0.42 & 1.14 & 3.57 \\
\hline Credit - Deposit Ratio & 79.98 & 13.74 & 49.20 & 114.77 \\
\hline Soundness- & & & & \\
\hline Capital adequacy ratio - Tier I & 10.99 & 2.93 & 5.85 & 18.64 \\
\hline Capital adequacy ratio - Tier II & 3.98 & 1.83 & 0.17 & 8.80 \\
\hline
\end{tabular}

Figure 1:-Comparing liquidity indicators between new and old private sector banks.

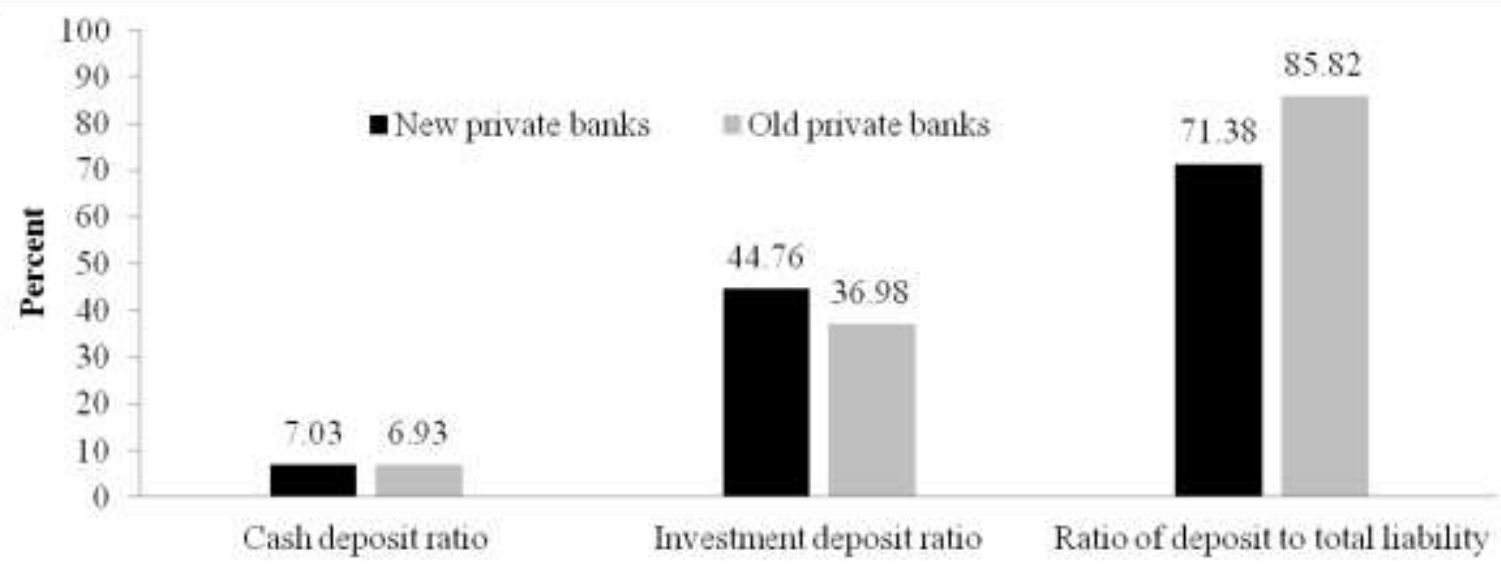

As far as ratios under asset quality of banks are concerned, secured advance to total advance come to 90.60 per cent which is higher for old private sector banks as compared with 80.21 per cent for new private sector banks (Figure 2). Ratio of net NPA to net advance is 3.09 per cent that is also greater for old private sector banks as against 1.66 per cent for new private sector banks. Hence, asset quality position is quite better for new private sector banks in comparison with old private sector banks. 
Figure 2:-Comparing asset quality indicators between new and old private sector banks.

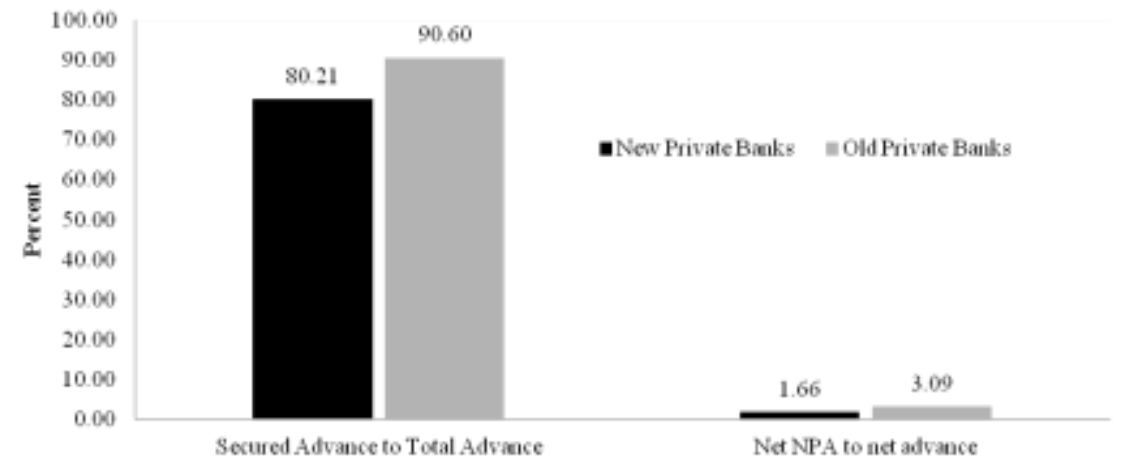

Management efficiency is far more superior for new private sector banks. As indicated from its indicators, it is observed that, business per employee, an important indicator shows that private sector banks deliver more than double business against old private sector banks.

Figure 3:-Comparing management efficiency indicators between new and old private sector banks.

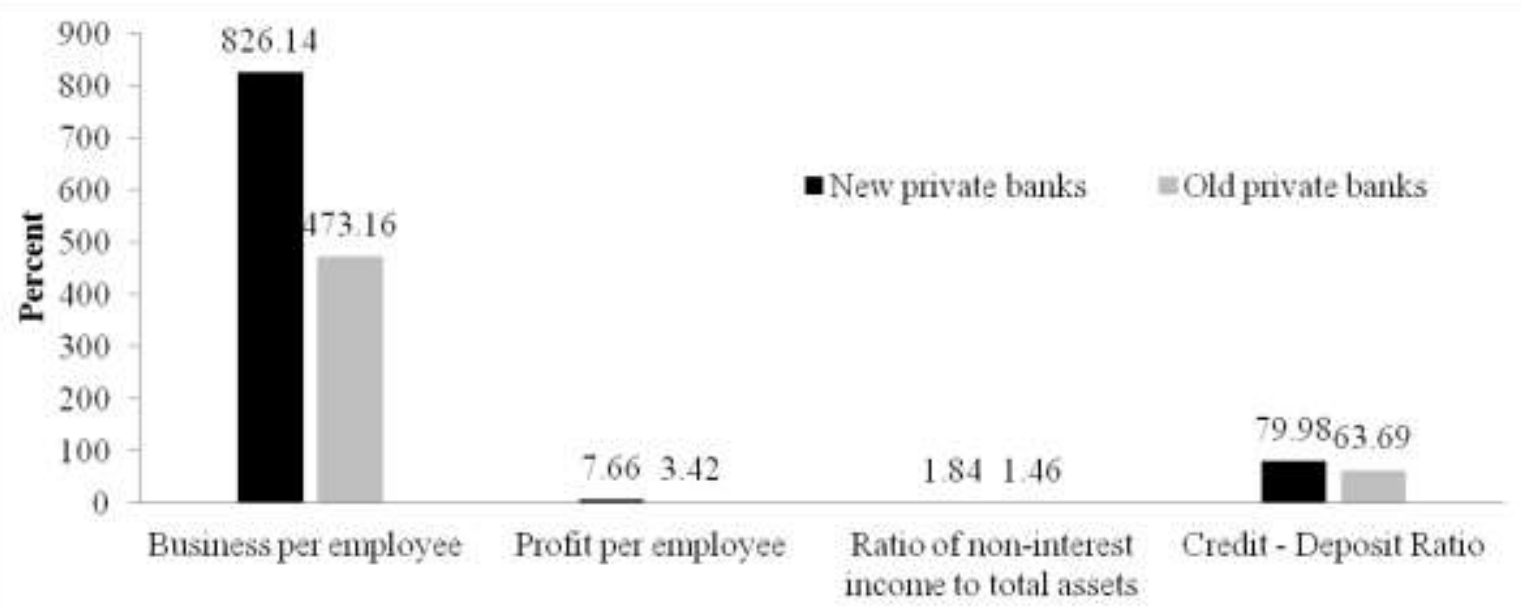

The average profit per employee come to Rs.7.66 million per annum for new private sector banks as against Rs.3.42 million per annum for old private sector banks (Figure 3). This indicates that the business per employee per annum is almost double for new private sector banks as compared with old private sector banks. As far other income of banks are concerned, the ratio of non-interest income to total assets is higher for new private sector banks (1.84 per cent) as compared with old private sector banks (1.46 per cent). Credit-deposit ratio also reflects the management performance of banks which is higher for new private sector banks (79.98 per cent) than old private sector banks (63.69 per cent). 
Figure 4:-Comparing capital adequacy indicators between new and old private sector banks.

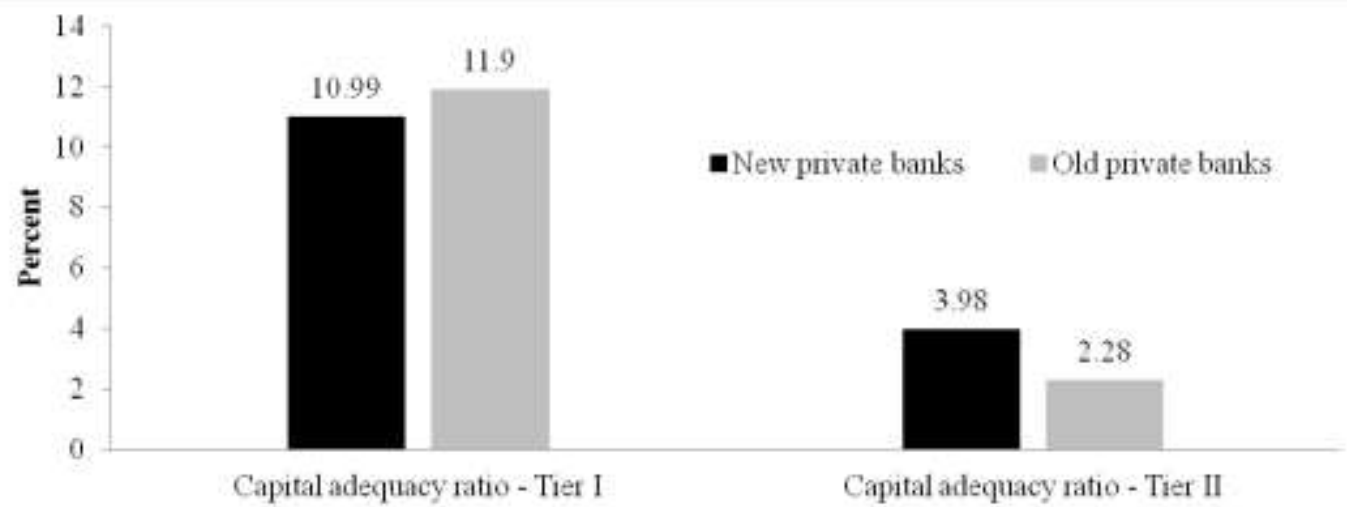

As indicated earlier, the soundness of banks is measured through capital adequacy ratios, both Tier-I and Tier-II. It is an important indicator which a bank has to maintain in order to gain confidence of the depositors and preventing banks from going bankrupt. Capital is seen as a cushion to protect the depositors and to promote the stability and proficiency of financial system around the globe. The average capital adequacy ratio (Tier-I) is higher for old private sector banks (11.90 per cent) than new private sector banks (10.99 per cent). However, the capital adequacy (Tier-II) is higher for new private sector banks (3.98 per cent) as compared with old private sector banks (2.28 per cent) [Figure 4].

Table 2:-Summary statistics of the determinants of performance, 2000-2014.

(Old Private Sector Banks)

\begin{tabular}{|l|c|c|c|c|}
\hline Variables & Mean & StDev & Min & Max \\
\hline Liquidity - & & & & \\
\hline Cash deposit ratio & 6.93 & 2.13 & 3.42 & 14.88 \\
\hline Investment deposit ratio & 36.98 & 7.06 & 25.31 & 66.80 \\
\hline Ratio of deposit to total liability & 85.82 & 5.13 & 63.23 & 92.91 \\
\hline Asset quality- & & & & \\
\hline Ratio of secured advances to total advances & 90.60 & 5.00 & 70.52 & 98.08 \\
\hline Ratio of net NPA to net advances & 3.09 & 3.21 & 0.03 & 15.85 \\
\hline Efficiency- & & & & \\
\hline Business per employee & 473.16 & 281.66 & 92.30 & 1201.00 \\
\hline Profit per employee & 3.42 & 2.89 & -1.73 & 13.90 \\
\hline Ratio of non-interest income to total assets & 1.46 & 0.71 & 0.36 & 4.18 \\
\hline Credit - Deposit Ratio & 63.69 & 10.44 & 37.34 & 93.29 \\
\hline Soundness- & & & & \\
\hline Capital adequacy ratio - Tier I & 11.90 & 6.50 & 70.52 & 55.93 \\
\hline Capital adequacy ratio - Tier II & 2.28 & 1.33 & 0.03 & 5.65 \\
\hline
\end{tabular}

Among the external factors considered in this study, the average GDP is 7 per cent per annum during the entire study period, while minimum and maximum value varies between 3.80 per cent and 10.26 per cent. The average inflation is 6.87 per cent, which varies between 3.68 per cent and 11.99 per cent during the study period.

Table 3:-Summary statistics of the determinants of performance, 2000-2014.

(Macroeconomic factors)

\begin{tabular}{|l|c|c|c|c|}
\hline Variables & Mean & StDev & Min & Max \\
\hline GDP Growth & 7.00 & 2.183 & 3.804 & 10.26 \\
\hline Inflation & 6.871 & 2.861 & 3.684 & 11.992 \\
\hline
\end{tabular}

\section{Correlation between the variables:-}

The correlation between the bank-specific and macroeconomic determinants with profitability reveals that management efficiency is found to be significantly correlated with banks' profitability at 0.01 level of significance 
as presented in Table 4. The Person correlation coefficient is higher for new private sector banks (0.528) as compared with old private sector banks (0.450). The next significant correlation is found between profitability and asset quality of new private sector banks $(0.342)$. However, the correlation is not significant for old private sector banks. Further, among external factors, GDP growth is not correlated with profitability for both categories of banks. Inflation is negatively related with banks' profitability, the coefficient is stronger for new private sector banks as compared with old private sector banks. This correlation exercise only gives a preliminary idea about the driving forces behind the growth of banks' profitability for different categories of banks. In order to investigate the impact of the each determinant on profitability separately on profitability we have conducted panel data regression analysis which is discussed in the next section.

Table 4:-Pairwise correlation coefficient (profitability vs determinants).

\begin{tabular}{|l|c|c|}
\hline & $\begin{array}{c}\text { Profitability } \\
\text { New Private Sector Banks }\end{array}$ & $\begin{array}{c}\text { Profitability } \\
\text { Old Private Sector Banks }\end{array}$ \\
\hline Liquidity & 0.018 & 0.188 \\
\hline Asset quality & $0.342^{*}$ & $0.380^{*}$ \\
\hline Management Efficiency & $0.528^{*}$ & $0.450^{*}$ \\
\hline Soundness & $0.456^{*}$ & 0.065 \\
\hline GDP Growth & 0.058 & 0.082 \\
\hline Inflation & 0.375 & -0.239 \\
\hline
\end{tabular}

Note: * Correlation is significant at the 0.01 level (2-tailed).

\section{Results of panel regression:-}

Table 5 presents the result of regression using panel data of banks. We have 7 new private sector banks and 12 old private sector banks. Thus, for 15 years time period we have 105 observations from new private sector banks and 180 observations from old private sector banks. Upon investing the result it is observed that the Breusch-Pagan Lagrange-Multiplier test indicates the presence of bank-specific unobserved heterogeneity for both categories of banks. The Hausman-Specification test (which checks whether those unobserved heterogeneity is correlated with our explanatory variables or not) shows that the omitted variables are not correlated with the determinants. Hence, we go for the Random-Effect estimates for these regressions.

Table 5:-Regression Results.

\begin{tabular}{|l|c|c|c|c|}
\hline \multirow{2}{*}{ Dependent Variable } & \multicolumn{2}{|c|}{$\begin{array}{c}\text { New Private Sector Banks } \\
\text { (Random Effect Model) }\end{array}$} & \multicolumn{2}{c|}{$\begin{array}{c}\text { Old Private Sector Banks } \\
\text { (Random Effect Model) }\end{array}$} \\
\cline { 2 - 5 } & Coefficient & Standard Error & Coefficient & 0.224 \\
\hline Liquidity & 0.152 & 0.201 & $0.309^{\mathrm{c}}$ & 0.157 \\
\hline Asset quality & 0.118 & 0.233 & $0.520^{\mathrm{a}}$ & 0.232 \\
\hline Efficiency & $0.629^{\mathrm{a}}$ & 0.130 & 0.247 & 0.167 \\
\hline Soundness & $0.307^{\mathrm{b}}$ & 0.162 & 0.035 & 0.028 \\
\hline GDP Growth & 0.014 & 0.015 & $-0.035^{\mathrm{c}}$ & 0.032 \\
\hline Inflation & 0.022 & 0.032 & $-0.558^{\mathrm{a}}$ & 0.270 \\
\hline Financial Crisis & 0.022 & 0.032 & 0.988 & 0.499 \\
\hline Constant & 1.940 & 0.347 & $5.27^{\mathrm{a}}$ & \\
\hline $\mathrm{R}^{2}$ & 0.375 & & $16.38^{\mathrm{a}}$ & \\
\hline F Statistics & $10.29^{\mathrm{a}}$ & & 180 & \\
\hline Breusch-Pagan & $3.28^{\mathrm{b}}$ & & & \\
\hline $\begin{array}{l}\text { Number of } \\
\text { observations }\end{array}$ & 70 & & & \\
\hline
\end{tabular}

Notes:- Significant at the less than $1 \%$ (a), $1-5 \%$ (b), $5-10 \%$ (c) levels of significance.

In order to convert the data set of new private sector banks into balanced panel we have omitted five years from 2000 - 2005 from the data set.

We now take a look at the result of the regression analysis which is presented in Table 5. It can be seen that, all variables related to the internal factors of banks show the expected positive sign. The results show that the modelling has quite good explanatory power. From the estimated coefficients one may observe that the determinants related to 
internal factors of banks are positively and significantly affected in majority of cases. The model fit well for the two categories of banks as observed from the high $\mathrm{R}^{2}$ values. All the four chosen determinants related banks internal factors have positive effect on profitability. As far as new private sector banks are concerned, management efficiency has strong influence on profitability, followed by financial soundness. The effect of liquidity on profitability is insignificant as indicated by the coefficient. This may due to the fact that liquidity is determined outside by RBI where all banks have to follow the norms from time to time. Among macroeconomic determinants, both GDP growth and inflation have positive impact on profitability for new private sector banks, but the coefficients are insignificant. For old private sector banks, inflation has significant negative effect on profitability. However, the magnitude is small. Post-crisis situation is positive for new private sector banks as indicated by the coefficient, which is positive but not significant. Favourable macroeconomic situation after financial crisis and rapid adoption of technology in banking operation has helped new private sector banks score over other categories of banks on profitability.

Among old private sector banks, all the variables related to internal performance of banks are positive and significantly affect on profitability, except soundness. As far as the magnitude of impact is concerned, management efficiency has highest impact, followed by asset quality and liquidity. Among macro indicators, GDP growth affect positively on profitability significantly. However, the magnitude of impact is very small as compared to other variables. Inflation has no impact on profitability. Financial crisis has big negative impact on profitability, which is actually deteriorated the performance of banks during post-crisis period. This indicates that post-crisis situation is not favourable for them, due to increased competition among banks' groups and adoption of technology which pushed them behind as compared with new private sector banks.

\section{Summary and Conclusion:-}

Overall results indicate that the magnitudes of impact of the internal factors of banks are similar in nature for both old and new private sector banks. Efficiency of bank management is most important determinants that affect profitability, while liquidly has least impact on it. Among macroeconomic determinants, GDP growth and inflation does not have meaningful impact on both groups of banks. However, financial instability made the banking sector vulnerable for both categories of banks, where the effect is significantly higher for new private sector banks as compared with old private sector banks. Appropriate risk policies should be practised by both categories of banks in order to cope with any financial instability in the economy.

\section{Appendix:- \\ Multicolineriety Check:-}

Table A1:-New Private Sector Banks.

\begin{tabular}{|l|c|c|c|c|c|c|c|}
\hline & Liquidity & $\begin{array}{c}\text { Asset } \\
\text { quality }\end{array}$ & Efficiency & Soundness & $\begin{array}{c}\text { GDP } \\
\text { Growth }\end{array}$ & Inflation & $\begin{array}{c}\text { Financial } \\
\text { Crisis }\end{array}$ \\
\hline Liquidity & 1.000 & & & & & & \\
\hline Asset quality & -0.012 & 1.000 & & & & & \\
\hline Efficiency & -0.115 & -0.176 & 1.000 & & & & \\
\hline Soundness & 0.171 & 0.083 & 0.411 & 1.000 & & & \\
\hline GDP Growth & -0.101 & 0.012 & -0.318 & -0.188 & 1.000 & & \\
\hline Inflation & -0.152 & 0.011 & 0.370 & 0.615 & -0.149 & 1.000 & \\
\hline Financial Crisis & -0.025 & -0.060 & 0.537 & 0.734 & -0.152 & 0.706 & 1.000 \\
\hline
\end{tabular}

Table A2:-Old Private Sector Banks.

\begin{tabular}{|l|c|c|c|c|c|c|c|}
\hline & Liquidity & $\begin{array}{c}\text { Asset } \\
\text { quality }\end{array}$ & Efficiency & Soundness & $\begin{array}{c}\text { GDP } \\
\text { Growth }\end{array}$ & Inflation & $\begin{array}{c}\text { Financial } \\
\text { Crisis }\end{array}$ \\
\hline Liquidity & 1.000 & & & & & & \\
\hline Asset quality & -0.085 & 1.000 & & & & & \\
\hline Efficiency & 0.003 & -0.121 & 1.000 & & & & \\
\hline Soundness & -0.054 & 0.070 & 0.096 & 1.000 & & & \\
\hline GDP Growth & -0.141 & 0.386 & -0.344 & 0.160 & 1.000 & & \\
\hline Inflation & 0.010 & 0.564 & 0.109 & 0.063 & 0.230 & 1.000 & \\
\hline Financial Crisis & -0.041 & 0.413 & 0.283 & 0.077 & 0.162 & 0.814 & 1.000 \\
\hline
\end{tabular}


Table A3:-VIF and Tolerance values.

\begin{tabular}{|c|c|c|c|c|c|}
\hline \multicolumn{3}{|c|}{ New Private Sector Banks } & \multicolumn{3}{|c|}{ Old Private Sector Banks } \\
\hline Variable & VIF & 1/VIF & Variable & VIF & 1/VIF \\
\hline Financial crisis & 3.60 & 0.272 & Inflation & 3.76 & 0.267 \\
\hline Soundness & 2.42 & 0.399 & Financial Crisis & 3.40 & 0.293 \\
\hline Inflation & 2.13 & 0.461 & Asset quality & 1.65 & 0.560 \\
\hline Efficiency & 1.58 & 0.594 & GDP Growth & 1.38 & 0.710 \\
\hline Liquidity & 1.12 & 0.858 & Efficiency & 1.34 & 0.718 \\
\hline GDP Growth & 1.13 & 0.860 & Soundness & 1.06 & 0.947 \\
\hline Asset quality & 1.08 & 0.890 & Liquidity & 1.04 & 0.962 \\
\hline Mean VIF & 1.87 & & Mean VIF & 1.94 & \\
\hline
\end{tabular}

\section{References:-}

1. Athanasoglou, P., Brissimis, S., \& Delis, M. (2008): Bank-specific, industry-specificand macroeconomic determinants of bank profitability. Journal of InternationalFinancial Markets, Institutions and Money, 18(2), $121-136$.

2. Athanasoglou, P.P., Brissimis, S.N., Delis, M.D., (2005): Bank-Specific, Industry-Specific and Macroeconomic Determinants of Bank Profitability, Bank of Greece, Working Paper No. 25.

3. Baltagi, Badi H. (2001): Econometric Analysis of Panel Data. Wiley, John \& Sons.

4. Devanadhen.K (2013): "performance evaluation of large size commercial banks in India", Indian journal of Finance, January. pp. 5-16.

5. Dietrich, a. \& G. Wanzenried (2014): The determinants of commercial banking profitability in low, middle and high income countries, The Quarterly Review of Economics and Finance, 54, pp. 337-354.

6. Greene, W. H. (2008): Econometric analysis, 6th ed., Upper Saddle River, N.J. : Prentice Hall.

7. Kennedy, P. (2008): A Guide to Econometrics, 6th ed. Malden, MA: Blackwell Publishing.

8. Makkar, A. and S. Singh (2013): Analysis of the financial performance of Indian commercial banks: A comparative study, Indian Journal of Finance, Volume 7, Issue 5, pp.41-49, 2013.

9. Ongore V. O. and G. B. Kusa (2013): Determinants of Financial Performance of Commercial Banks in Kenya, International Journal of Economics and Financial Issues, Vo. 3, No. 1.

10. Ranjan, R. and Dhal, Surat, C., (2003): "Non-Performing Loans and Terms of Credit of Public Sector Banks in India: An Empirical Assessment”, RBI occasional papers, RBI Publications, 24(3), pp. 81-121.

11. Shukla, S. (2016): Performance of the Indian banking industry: A comparison of public and private sector banks, Indian Journal of Finance, Volume 10, Issue 1, pp. 41-55.

12. Vong, A. P. I., \& Chan, H. S., (2009): "Determinants of bank profitability in Macao", Macau Monetary Research Bulletin, 12(6), 93-113. 